\title{
WAKAF HAK MILIK ATAS SATUAN RUMAH SUSUN
}

\author{
A. Fauzi Aziz \\ Institut Agama Islam Bani Fattah Jombang, Indonesia \\ Email: mahrusabi@gmail.com
}

Abdul Chalim Nur

Institut Agama Islam Bani Fattah Jombang, Indonesia

Email: mahrusabi@gmail.com

\begin{abstract}
Abstrak
Akhir-akhir ini banyak permasalahan rumah susun yang mencuat dipermukaan, hal tersebut dikarenakan tingginya infestasi rumah susun yang tidak dibarengi dengan pengetahuan hukum yang terkait dengan rumah susun di kalangan masyarakat luas. Perumahan merupakan salah satu kebutuhan dasar manusia baik itu sebagai tempat tinggal, usaha perkantoran, usaha berjualan dan lain sebagainya. Kita semua mengetahui bahwa untuk mencari rumah yang layak diperkotaan sangatlah sulit yang hal ini disebabkan karena terbatasnya lahan tanah didaerah perkotaan.

Undang Undang No 41 Tahun 2004 Tentang Wakaf pada mulanya dilatarbelakangi dengan tujuan memajukan kesejahteraan umat, maka UU ini manjadikan hak milik atas satuan rumah susun sebagai harta benda wakaf. Mengingat bahwa tujuan dari rumah susun adalah untuk sebagai tempat tinggal dan atau hunian, maka tentu saja hak milik atas satuan rumah susun memiliki nilai ekonomis yakni dengan menyewakan kemanfaatannya kepada pihak lain, dan diperuntukkan untuk tujuan wakaf. Pembangunan rumah susun merupakan salah satu alternatif pemecahan masalah


kebutuhan perumahan dan pemukiman terutama di daerah perkotaan yang jumlah penduduknya terus meningkat.

Keyword: Wakaf, Maslahah, Rumah Susun

\section{Pendahuluan}

Harta Wakaf dalam Pasal 16 (1) UU No 41 Tahun 2004 Tentang Wakaf, dinyatakan: "Harta benda wakaf terdiri dari a. benda tidak bergerak dan b. bergerak" . Lebih lanjut wakaf hak milik atas satuan rumah susun dapat dijadikan harta benda wakaf. Dalam Pasal 16 (2) point d disebutkan "hak milik atas satuan rumah susun sesuai dengan ketentuan peraturan perundang-undangan yang berlaku. ${ }^{1}$ Hak milik atas satuan rumah susun juga meliputi hak atas bagian bersama, benda bersama, dan tanah bersama, yang merupakan satu kesatuan yang tidak terpisahkan dengan satuan yang bersangkutan. ${ }^{2}$

Mengkaji wakaf hak milik atas satuan rumah susun sebenarnya membahas perluasan makna harta benda wakaf yang inovatif dalam UU No 41 Tahun 2004 Tentang Wakaf yaitu untuk kesejahteraan umat. Gairah penulis kemudian bangkit untuk mengkaji wakaf hak milik atas satuan rumah susun, disamping keinginan untuk menganalisa hukum satuan rumah susun menurut perundang-undangan yang berlaku juga dikarenakan terjadi pergolakan pendapat fikih Islam yang tajam dalam rumah susun yang karena di dalamnya terdapat unsur bersama atas hak dalam rumah susun.

\section{Pengertian Wakaf}

Secara bahasa, wakaf berasal dari bahasa arab Al-Waqf bentuk mașdar dari Waqafa-Yaqifu-Waqfa. ${ }^{3}$ Kata $A l$-Waqf semakna dengan kata Al-Habs bentuk masdar dari Habasa-Yahbisu-Habsa yang artinya menahan. ${ }^{4}$ Kata Waqafa dalam bahasa arab merupakan sinonim dari dari kata Habasa-Yahbisu-Habsa yang menurut bahasa juga berarti menahan. Wakaf juga dapat diartikan benda bergerak atau tidak bergerak yang disediakan untuk kepentingan umum (Islam) sebagai pemberian yang ikhlas, kata "mewakafkan" berarti memperuntukkan bagi umum atau keperluan yang berkaitan dengan agama. ${ }^{5}$ Rasulullah SAW menggunakan

\footnotetext{
${ }^{1}$ Pasal 16 (1) UU No 41 Tahun 2004 Tentang Wakaf

2 Pasal 8 (3) UU No 16 Tahun 1985 Tentang Rumah Susun

3 A.W. Munawwir, Kamus al-Munawnir Arab-Indonesia Terlengkap, (Surabaya: Pustaka Progressif, 1997), 1576.

${ }^{4}$ al-Sayyid Sābiq, Fiqh al-Sunnah, Juz III, (Kairo: Dār al-Fatḥ, 1995), 515.

${ }^{5}$ Departeman Pendidikan Nasional. Kamus Besar Bahasa Indonesia. (Jakarta: PT Gramedia Pustaka Utama, 2008), 1553.
} 
kata al-Habs dalam menunjukkan pengertian wakaf. Dengan demikian yang dimaksud dalam pembahasan ini ialah menahan (al-Habs), yaitu menahan suatu harta benda, yang manfaatnya diperuntukkan bagi kebajikan yang dianjurkan oleh agama. ${ }^{6}$

Dari berbagai pengertian wakaf menurut bahasa di atas, dapat disimpulkan bahwa al-Habs maupun al-Waqf sama-sama mengandung makna menahan harta benda baik bergerak atau tidak bergerak serta manfaatnya didermakan atau diperuntukkan untuk kepentingan umum selama dibenarkan oleh agama atau kepentingan yang berhubungan dengan agama.

Sedangkan secara istilah para ulama' fikih berbeda pendapat. Mereka mendefinisikan wakaf dengan definisi yang beragam, di antara definisi tersebut adalah sebagai berikut:

a. Mażhab Ḥanafi

$$
\text { (حبس العين على) حكم (الوا قف والتصدق بالمنفعة) ولو في الجملة7 }
$$

"Wakaf adalab menahan harta dibawah tangan Wäkif, dan menyedekabkan manfaatnya, meskipun secara global".

Dalam kitab Syarkh Fath al-Qadì, Burhānuddīn Ali bin Abi Bakr al-Marghināni memberikan pengertian:

$$
\text { والتصدق بالمنفعة بمنزلة وهو في الشرع عند أبي حنيفة حبس العين على ملك الواقف } 8
$$

"Menurut Abu Hanifah, wakaf adalah menahan atas kepemilikan

harta Wäqif dan kemanfaatannya disedekabkan, serta wakaf disejajarkan dengan 'äriyah (pinjaman)"

Atas dasar pengertian wakaf Mażhab Hanafi di atas wakaf adalah menahan harta benda tanpa menghilangkan hak kepemilikan benda tersebut dan manfaatnya disedekahkan untuk kebajikan. Kepemilikan terhadap harta wakaf masih milik Wäqif karena dikategorikan dengan istilah 'áriyah (pinjaman).

\footnotetext{
${ }^{6}$ Departemen Agama, Wakaf Tunai Dalam Perspektif Hukum Islam, (Jakarta: Dirjen Bimas Islam Dan Penyelenggaraan Haji, 2005), 13- 14.

${ }^{7}$ Ibn Abidin, Hāsyiah Radd al-Mukhtār, Juz IV (Beirut Lebanon : Dār al-Fikr, 2005), 532.

${ }^{8}$ Kamaluddin Muhammad bin Abdul wahid, Syarkh Fath al-Qadìr, Juz VI (Beirut Lebanon: Dār al-Kutub al-Ilmiah, 1995), 189- 190.
} 
Kelompok Hanafi membolehkan menjual dan menukar sekalian benda-benda wakaf khās dan 'àm kecuali masjid. Mereka membolehkan tersebut dengan tiga keadaan, yaitu:

1. Orang yang berwakaf mensyaratkan hal itu ketika berwakaf

2. Harta wakaf itu tidak dapat dimanfaatkan lagi

3. Pertukaran itu mendatangkan manfaat yang lebih baik dan harga yang lebih mahal. ${ }^{9}$

Abu Hanifah membuat Istinbat al-Hukmi atas dasar wakaf dengan Qaul Rasulullah SAW " "لا حبس عن فرا ئ أله ", dengan demikian, jika wakaf berakibat pada hilangnya kepemilikan terhadap harta, maka hal tersebut adalah suatu tindakan Habs (berhenti) atas pusaka atau harta, sedangkan harta pada akhirnya ditinggalkan diantara ahli waris dan diantara bagian pasti mereka (ahli waris). Hadis Yang diriwayatkan oleh Syuraih, bahwa sesunggunya ia telah mengatakan جاء محد ص.م بييع الحبس , maka boleh menjual Manqüf (harta wakaf) serta menunjukan bahwa wakaf tidak berakibat hilangnya kepemilikan. ${ }^{10}$

b. Mażhab Maliki

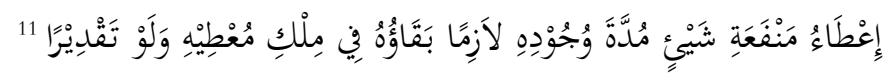
"Memberikan manfaat dari sesuatu ketika sesuatu itu masih ada dengan tetapnya bak kepemilikean benda pada orang yang memberikan walaupun banya kiasan".

$$
\text { بصيغة مدة ما يراه المحبس المالك منفعة مملوكة ولو كان مملوكا باجرة او جعل غلته كدراهم لمستحق }
$$

"Menjadikan manfaat harta sang Wäqif baik berupa sewa atau basilnya untuk diserabkan kepada orang yang berbak, dengan bentuk penyerahan berjangka waktu sesuai dengan apa yang dikehendaki oleh Wäkif.

${ }_{9}^{9}$ Direktorat Pemberdayaan Wakaf, Fiqih Wakaf., (Departemen Agama RI. Jakarta:2006). 2

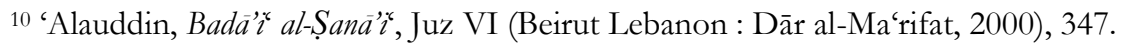

11 Muhammad 'Ulaysh, Mankh al-Jalil Syarkh ala Mukhtașar Sayyid Khalīl, (Beirut Lebanon: Dār al-Fikr,1989), 108.

12 Wahbah al-Zuhaily, al-Figh al-Islāmi wa Adillatubu Juz X (Beirut: Dār al-Fikr,1997), 7602 . 
Mażhab Maliki bependapat bahwa wakaf itu tidak melepaskan harta yang diwakafkan dari kepemilikan $W a ̈ k i f$, namun wakaf tersebut mencegah Wäqif melakukan tindakan yang dapat melepaskan kepemilikannya atas harta tersebut kepada yang lain dan Wäqif berkewajiban menyedekahkan manfaatnya serta tidak boleh menarik kembali wakafnya. Perbuatan siWäqif menjadikan manfaat hartanya untuk digunakan oleh mustahiq (penerima wakaf), walaupun yang dimilikinya itu berbentuk upah, atau menjadikan hasilnya untuk dapat digunakan seperti mewakafkan uang. Wakaf dilakukan dengan mengucapkan lafadz wakaf untuk masa tertentu sesuai dengan keinginan pemilik. Dengan kata lain, pemilik harta menahan benda itu dari penggunaan secara pemilikan, tetapi membolehkan pemanfaatan hasilnya untuk tujuan kebaikan, yaitu pemberian manfaat benda secara wajar sedang benda itu tetap menjadi milik si Wäkif. Perwakafan itu berlaku untuk suatu masa tertentu, dan karenanya tidak boleh disyaratkan sebagai wakaf kekal (selamanya). ${ }^{13}$

Wakaf menurut interpretasi Malikiyah, tidak terputus hak siWäqif terhadap benda yang di wakafkan. Yang terputus itu hanyalah dalam hal bertașarruf. Malikiyah beralasan dengan Hadis Ibnu Umar. Ketika Rasulullah menyatakan, "jika kamu mau, tahanlah asalnya dan sedekahkanlah hasilnya". Dari kalimat ini menurut Maliki adalah isyarat dari Rasul kepada umat untuk mensedekahkan hasilnya saja. ${ }^{14}$

Wakaf dilakukan dengan mengucapkan lafadz wakaf untuk masa tertentu sesuai dengan keinginan pemilik. Dengan kata lain, pemilik harta menahan benda itu dari penggunaan secara pemilikan, tetapi membolehkan pemanfaatan hasilnya untuk tujuan kebaikan, yaitu pemberian manfaat benda secara wajar namun benda itu tetap menjadi milik siWäkif..$^{15}$

Adapun Ulama Maliki berpendapat bahwa harta wakaf tidak boleh di jual dalam tiga keadaan, yakni:

1. Orang yang mewakafkan mensyaratkan tidak boleh menjual sewaktu ada perjanjian wakaf tersebut, lalu ia mengikuti syarat itu.

2. Benda yang di wakafkan itu termasuk jenis benda yang bergerak dan tidak pantas bagi pihak si penerima wakaf lalu benda wakaf itu dijual

13 Direktorat Pemberdayaan Wakaf, Fiqih Wakaf., (Departemen Agama RI. Jakarta:2006), 2-3.

${ }^{14}$ Ibid, 4.

15 Suparman Usman, Hukum ..., 25. 
dan harganya di belikan pada hal yang seumpama dan sebanding dengannya. ${ }^{16}$

3. Tumbuh-tumbuhan yang dijual itu untuk kepentingan perluasan masjid atau jalan pekuburan dan pada hal-hal lainnya yang tidak boleh dijual. ${ }^{17}$

c. Mażhab Syāfici

Istinbat al-Hukmi wakaf menurut Mażhab Syāfici adalah Hadis Umar R.A yang menunjukkan bahwa $W$ äqif tercegah atas pentașaruffannya atas harta wakaf yang karenanya pula kata Habs diartikan -dimaknai- dengan pengertian منع -tercegah- yang dalam hal ini tercegahnya harta untuk dimiliki dan tercegah untuk ditasharufkan atas kepemilikan. Berdasarkan atas serangkaian peristiwa 'amaliah wakaf sejak awal Islam hingga sekarang menunjukkan makna tentunya bahwa wakaf atas harta untuk kebaikan dan tercegahnya $W$ äqif untuk mentasharufkan atas harta yang telah diwakafkan. ${ }^{18}$

Berdasarkan pengertian ini, mażhab Syāfíci memiliki sikap yang sangat tegas terhadap kepemilikan harta wakaf, yaitu dengan sahnya wakaf maka kepemilikan harta wakaf telah berpindah kepada Allah, dalam arti milik umat, dan bukan lagi milik orang yang mewakafkan dan juga milik nādżir pekerja pengelola wakaf. ${ }^{19}$

\section{d. Mażhab Hanbali}

Mażhab Hanbali mengemukakan ijtibädnya bahwa apabila seseorang telah mewakafkan hartanya, maka ia tidak lagi memiliki kekuasan bertindak atas harta benda yang diwaqafkan tersebut, dan wakaf berlaku untuk selamanya. Hanbali juga mengemukakan bahwa harta yang telah diwakafkan tidak boleh ditarik kembali. Ia juga mengemukakan ijtiha $\bar{d}$ bahwa benda yang diwakafkan itu haruslah benda yang boleh dijual, namun setelah menjadi wakaf tidak boleh dijual. ${ }^{20}$

Dalam hal ini, Suparman Usman dalam bukunya Hukum Perwakafan di Indonesia menjelaskan bahwa Mażhab Hanbali sependapat dengan Mażhab Syāfíi dalam mendefinisikan wakaf, yang intinya hasil

\footnotetext{
${ }^{16}$ Direktorat Pemberdayaan Wakaf, Fiqih..., 4.

${ }^{17}$ Ibid, 3

18 Wahbah al-Zuhaily, al-Fiqh al-Islämi wa Adillatubu Juz X (Beirut: Dār al-Fikr,1997), 7603.

${ }^{19}$ Departemen Agama, Wakaf Tunai..., 18.

${ }^{20}$ Wahbah al-Zuhaily, al-Figh..., 7605

40 A. Fauzi Aziz \& Abdul Chalim Nur - Wakaf Hak Milik Atas Satuan Rumah Susun
} 
dari benda (wakaf) tersebut digunakan untuk kebaikan dalam rangka mendekatkan diri kepada Allah SWT. Atas dasar itu, benda wakaf tersebut lepas dari pemilikan siWäqif dan menjadi hak Allah SWT. Kewenangan $W$ äqif atas harta itu hilang, bahkan ia wajib menyedekahkan sesuai dengan tujuan wakaf. ${ }^{21}$

Sedangakan menurut Pasal 1 UU No. 41 Tahun 2004 Tentang Wakaf, "wakaf adalah perbuatan hukum Wäqif untuk memisahkan dan/atau menyerahkan sebagian harta benda miliknya untuk dimanfaatkan selamanya atau untuk jangka waktu tertentu sesuai dengan kepentingannya guna keperluan ibadah dan/atau kesejahteraan umum menurut syari'ah. ${ }^{22}$

Kemudian dalam Pasal 125 Kompilasi Hukum Islam (KHI) dalam buku III tentang hukum perwakafan menyatakan: "wakaf adalah perbuatan hukum seseorang atau kelompok orang atau badan hukum yang memisahkan sebagian dari benda miliknya dan melembagakannya untuk selama-lamanya guna kepentingan ibadah atau keperluan umum lainnya sesuai dengan ajaran Islam." 23

Berdasarkan beberapa pengertian wakaf yang dikemukakan di atas, dapatlah disimpulkan bahwa pengertian wakaf adalah suatu perbuatan hukum dari seseorang yang dengan sengaja memisahkan atau mengeluarkan harta bendanya yang digunakan manfaatnya untuk keperluan di jalan Allah atau jalan kebaikan.

\section{Rukun Wakaf}

Rukun adalah sesuatu yang merupakan sendi utama dan unsur pokok dalam pembentukan sesuatu hal. Perkataan rukun berasal dari bahasa arab "ruknu" yang berarti tiang, penopang atau sandaran, ${ }^{24}$ atau dengan kata lain rukun adalah sesuatu yang harus dipenuhi untuk sahnya suatu perbuatan. ${ }^{25}$

Unsur-unsur wakaf (rukun-rukun wakaf) ada empat, yaitu:

1. Orang-Orang yang berwakaf (Wäkiff)

2. Sesuatu atau harta yang diwakafkan (Manqüf)

\footnotetext{
21 Suparman Usman, Hukum..., 25.

22 Departemen Agama, UU No 41 Tabun 2004 Tentang Wakaf \& PP No 42 Tabun 2006 Tentang Pelaksanaannya, (Surabaya : Kantor Wilayah Provinsi Jawa Timur, 2007), 3.

${ }^{23}$ Kompilasi Hukum Islam di Indonesia. (Jakarta: Akademika Pressindo, 1995), 165.

${ }^{24}$ Anton M. Moelyono, Kamus Besar Bahasa Indonesia, Cet. ke-2, Jakarta: Balai Pustaka, 1989), 757.

${ }^{25}$ Departemen Pendidikan Nasional. Kamus Besar Bahasa Indonesia Pusat Bahasa. Edisi IV (Jakarta: PT Pustaka Utama, 2008), 1187.
} 
3. Tempat kemana diwakafkan harta (Manqüf'alaih)

4. Aqad, yaitu suatu pernyataan timbang terima harta wakaf dari si $W a ̈ q i f$ kepada manqüf' 'alaih. ${ }^{26}$

\section{Macam- Macam Wakaf}

Menurut hukum islam wakaf terdiri dari dua macam, yaitu:

a. Wakaf Abli (wakaf keluarga)

Wakaf ahli atau biasa disebut wakaf wakaf keluarga atau wakaf khusus adalah wakaf yang tujuan peruntukannya ditujukan kepada orang-orang tertentu saja atau dilingkungan keluarganya. ${ }^{27}$ Misalnya seseorang mewakafkan bukubukunya kepada anak-anaknya dan diteruskan kepada cucu-cucunya saja yang dapat menggunakannya.

Pada perkembangan selanjutnya, wakaf abli ini dianggap kurang dapat memberikan manfaat bagi kesejahteraan umum, karena sering menimbulkan kekaburan dalam pengelolaan dan pemanfaatan wakaf itu oleh keluarga yang diserahi harta wakaf. Lebih-lebih kalau keturunan keluarga tersebut sudah berlansung kepada anak cucunya. ${ }^{28}$

Berdasakan pengalaman, maka wakaf abli atau keluarga ini biasanya akan menemui kesulitan apabila misalnya benda wakaf tersebut merupakan sebidang tanah pertanian, apabila sudah terlampaui waktu ratusan tahun, maka dalam melaksanakan wakaf sesuai dengan peruntukannya akan timbul kesulitan, yaitu cara mengimbangi rata hasil tanah pertanian tersebut. ${ }^{29}$

b. Wakaf Khairi

Wakaf Khairi adalah wakaf yang diperuntukkan bagi segala amal kebaikan atau kepentingan umum. Wakaf ini ditujukan kepada umum, dengan tidak terbatas penggunaannya, yang mencakup semua aspek untuk kepentingan dan kesejahteraan umat manusia pada umumnya. ${ }^{30}$

Wakaf inilah yang merupakan salah satu segi dan cara membelanjakan atau memanfaatkan harta dijalan Allah SWT. Dan tentunya kalau dilihat dari segi manfaat kegunaannya merupakan salah satu upaya sebagai sarana pembangunan, baik dibidang keagamaan khusus seperti peribadatan, perekonomian, kesehatan, keamanan, dan sebagainya. Dengan demikian, benda wakaf tersebut benar-benr terasa

\footnotetext{
${ }^{26}$ Suparman Usman, Hukum Perwakafan DiIndonesia, Cet. Ke-1, Jakarta: Darul Ulum Press, 1994), 32

${ }^{27}$ Saroso,dkk, Tinjauan Yuridis..., 8.

28 Suparman Usman, Hukum..., 35.

${ }^{29}$ Saroso, dkk, Tinjauan Yuridis..., 8.

30 Suparman Usman, Hukum..., 35-36.
} 
manfaatnya untuk kepentingan kemanusiaan atau kepentingan umum, tidak hanya untuk keluarga tertentu saja. ${ }^{31}$

\section{Syarat - Syarat Wakaf}

Untuk sahnya suatu wakaf, harus dipenuhi beberapa syarat dari unsur-unsur wakaf diatas, yaitu:

\section{Syarat Wakif}

Wäqif adalah orang atau orang-orang ataupun badan hukum yang mewakafkan tanah miliknya. Sedangkan orang atau orang-orang yang mewakafkan (Wäkif) tanah miliknya harus memenuhi syarat-syarat sebagai berikut ${ }^{32}$ :

a. Telah dewasa,

b. Sehat akalnya serta yang oleh hukum tidak terhalang untuk melakukan perbuatan hukum,

c. Atas kehendak sendiri dan tanpa paksaan orang lain.

d. Tidak terhalang oleh hukum untuk melakukan perbuatan hukum. ${ }^{33}$

Orang yang mewakafkan harus orang yang sepenuhnya berhak untuk menguasai benda yang akan diwakafkan. SiWäqif tersebut harus mukallaf (äqil bäligh) dan atas kehendak sendiri, tidak dipaksa orang lain. ${ }^{34}$

Menurut Azhar Basyir dalam bukunya Asas-asas Hukum Muamalat (Hukum Perdata Islam), menjelaskan bahwa orang yang mewakafkan (Wäkiff) disyaratkan memiliki kecakapan hukum atau kamālul abliyyah dalam membelanjakan hartanya. Kecakapan bertindak disini meliputi empat (4) kriteria, yaitu:

1) Wäqif harus merdeka dan pemilik penuh dari harta yang diwakafkan, tidak sah wakaf seorang budak karenanya tidak mempunyai hak milik.

2) Wäqif haruslah seseorang yang berakal sempurna, tidak sah wakaf dari Wäqif yang gila.

3) Wäqif harus orang yang baligh, karena tidak sah wakaf dari anak kecil baik sudah mumayyiz atau belum, sebab bāligh dipandang sebagai sempurnanya akal.

\footnotetext{
${ }^{31}$ Ibid, 36.

32 Ibid, 73.

33 Saroso,dkk, Tinjauan Yuridis Tentang Perwakafan Tanah Hak Milik,,Cet, Ke-1 (Yogyakarta: Liberty, 1984) 27.

${ }^{34}$ Suparman Usman, Hukum..., 32.
} 
4) Orang yang berwakaf harus orang yang mampu bertindak secara hukum (rasyid), artinya adalah dewasa yang menitikberatkan pada kematangan pertimbangan akal, bukan pada bilangan umur. ${ }^{35}$ Contohnya orang yang berada di bawah pengampuan dipandang tidak cakap untuk berbuat kebaikan (tabarru), maka wakaf yang dilakukannya tidak sah. Tetapi berdasarkan istihsān, wakaf orang yang berada di bawah pengampuan terhadap dirinya sendiri selama hidupnya hukumnya sah. Karena tujuan dari pengampuan adalah untuk menjaga harta wakaf supaya tidak habis dibelanjakan untuk sesuatu yang tidak benar, dan untuk menjaga dirinya agar tidak menjadi beban orang lain. ${ }^{36}$

Didalam pasal 1 ayat (2) PP No 28 Tahun 1977 disebutkan bahwa yang dapat menjadi $W$ äqif adalah ${ }^{37}$ :

a. Orang perseorangan

b. Orang-orang (bersama-sama)

c. Badan hokum

\section{Syarat Mauqūf Bih (Harta Benda Wakaf)}

Menurut Mażhab Syāfíi harta wakaf adalah harta yang manfaat dari harta wakaf itu kekal abadi, tidak habis dengan sekali pakai, untuk itu tidak sah makanan dan minyak wangi digunakan untuk wakaf. Wakaf atas harta tidak bergerak sah secara ijmā' ulama' dan harta tidak bergerak dan harta bersama (badan hukum).

Perbuatan mewakafkan memang perbuatan yang suci, mulia dan terpuji sesuai dengan ajaran islam. Berhubung dengan itu maka, tanahtanah (harta wakaf) yang hendak diwakafkan itu betul-betul merupakan milik bersih dan tidak ada cacatnya ditinjau dari sudut pemilikan. ${ }^{38}$

Seperti yang kita ketahui bahwasannya sifat-sifat harta (benda) yang diwakafkan adalah harta yang tahan lama dan bermanfaat, Karena dengan manfaat dari harta yang tahan lama tersebut itulah yang diharapkan pahala wakaf akan terus mengalir. Adapun syarat-syarat dari harta yang diwakafkan adalah:

\footnotetext{
35 Azhar Basyir, Asas-asas Hukum Muamalat (Hukum Perdata Islam), cet ke-2 (Yogyakarta:UII Pres, 2004), 31

36 Ibid.

${ }^{37}$ Saroso,dkk, Tinjauan Yuridis..., 27.

38 Suparman Usman, Hukum..., 74.
} 
a. Harta yang diwakafkan harus berupa benda yang bernilai (Mutaqawwam). ${ }^{39}$ Pengertian harta yang Mutaqawwam ialah segala sesuatu yang dapat disimpan dan halal digunakan dalam keadaan normal (bukan dalam keadaan darurat). Tidak sah mewakafkan sesuatu yang bukan harta, seperti manfaat dari rumah sewaan untuk ditempati.

b. Harta yang diwakafkan harus jelas wujud dan ukurannya agar tidak terjadi perselisihan dikemudian hari.

c. Harta yang diwakafkan harus jelas milik siWäqif dan juga merupakan benda milik yang bebas dari segala pembebanan, ikatan, dan sengketa dengan harta benda.wakaf yang dialihkan, hanya jika jika jelas-jelas untuk maslahat yang lebih besar.

Berdasarkan pandangan tersebut diatas, maka tanah yang mengandung pembebanan seperti bipotik, tanah dalam proses perkara dan sengketa, tidak dapat diwakafkan sebelum masalahnya diselesaikan terlebih dahulu. ${ }^{40}$

\section{Pandangan Ulama Terhadap Wakaf Manfaat Dalam Satuan Rumah Susun}

Perumahan dan pemukiman merupakan kebutuhan dasar setiap manusia. Dengan semakin bertambahnya penduduk, sedangkan lahan yang tersedia sangat terbatas, maka pembangunan rumah dibuat bertingkat atau yang kita kenal dengan rumah susun. Pembangunan rumah susun merupakan salah satu alternatif pemecahan masalah kebutuhan perumahan dan pemukiman terutama di daerah perkotaan yang jumlah penduduknya terus meningkat, karena pembangunan rumah susun dapat mengurangi penggunaan tanah, membuat ruang-ruang terbuka kota yang lebih lega dan dapat digunakan sebagai suatu cara untuk peremajaan kota bagi daerah yang kumuh.

Salah satu perbedaan UU No. 41 Tahun 2004 dengan Peraturan Pemerintah No. 28 Tahu 1977 adalah ruang lingkup substansi yang diaturnya. UU ini mengatur wakaf dalam lingkup yang lebih luas, tidak terbatas hanya pada wakaf tanah milik. UU ini membagi benda wakaf menjadi benda tidak bergerak dan benda bergerak. Benda tidak bergerak contohnya hak atas tanah, bagunan atau bagian bangunan, tanaman dan benda lain yang berkaitan dengan tanah, serta hak milik atas rumah susun. Sedangkan benda bergerak contohnya adalah uang, logam

${ }^{39}$ Wahbah al-Zuhaili, al-Fiqh al-Islämi..., 7634

${ }^{40} \mathrm{Ibid}, 74$. 
mulia, surat berharga, kendaraan, hak atas kekayaan intelektual dan hak sewa.

Saat ini Indonesia telah memiliki peraturan perundang-undangan yang mengatur mengenai rumah susun, yaitu Undang-Undang Nomor 16 Tahun 1985 Tentang Rumah Susun".

Menurut Undang-Undang Republik Indonesia Nomor 16 Tahun 1985 Tentang Rumah Susun menyatakan pengertian rumah susun adalah bangunan gedung bertingkat yang distrukturkan secara fungsional dalam arah horizontal dan vertikal yang terbagi dalam satuan-satuan yang masing-masing jelas batas-batasnya, ukuran dan luasnya, dan dapat dimiliki dan dihuni secara terpisah. Selain satuan-satuan yang penggunaannya terpisah dan bagian bersama dari bangunan tersebut serta benda bersama dan tanah bersama yang di atasnya didirikan rumah susun, yang karena sifat dan fungsinya harus digunakan dan dinikmati bersama dan tidak dapat dimiliki secara perseorangan. ${ }^{41}$

Dalam Undang-Undang Rumah Susun, rumah susun hanya dapat dibangun di atas tanah hak milik, hak guna bangunan, hak pakai atas tanah Negara atau hak pengelolaan sesuai dengan peraturan peundangundangan yang berlaku. Untuk rumah susun yang dibangun di atas tanah yang dikuasai dengan hak pengelolaan, wajib menyelesaikan status hak guna bangunannya terlebih dahulu sebelum menjual satuan rumah susun yang bersangkutan. ${ }^{42}$

Mengkaji wakaf hak milik atas satuan rumah susun sebenarnya membahas perluasan makna harta benda wakaf yang inovatif dalam UU No 41 Tahun 2004 Tentang Wakaf untuk kesejahteraan umat. Dan menganalisa hukum satuan rumah susun menurut perundang-undangan yang berlaku juga dikarenakan terjadi pergolakan pendapat fikih Islam yang tajam dalam rumah susun yang karena di dalamnya terdapat unsur bersama atas hak dalam rumah susun.

Ketentuan atas rumah susun dalam wakaf seperti yang dijelaskan diatas yaitu Mażhab Maliki yang dikutip oleh Abu Zahrah dalam kitab Syarkh al-kabir, yang argumennya tidak lain adalah bahwa ruang angkasa dapat diwakafkan jika ruang angkasa tersebut dapat diperjual belikan, dapat diserahterimakan, bahkan dari sisi kemanfaatannya juga dapat diperuntukkan bagi pemilik tanah dan peruntukan wakaf. ${ }^{43}$

Mażhab Maliki bependapat bahwa wakaf itu tidak melepaskan harta yang diwakafkan dari kepemilikan $W a ̈ k i f$, namun wakaf tersebut

\footnotetext{
${ }^{41}$ Pasal 1 (1) UU 16 Tahun 1985 Rumah Susun

42 Pasal 7 ayat (1), Undang-Undang Nomor 16 tahun 1985 tentang Rumah Susun

43 Abu Zahrah, Muhāẹarāt Fi al-Waqf, (Kairo: Dār al-Fikr al-Araby, 2005), 117 
mencegah Wäqif melakukan tindakan yang dapat melepaskan kepemilikannya atas harta tersebut kepada yang lain dan Wäqif berkewajiban menyedekahkan manfaatnya serta tidak boleh menarik kembali wakafnya. Perbuatan siWäqif menjadikan manfaat hartanya untuk digunakan oleh mustahiq (penerima wakaf). Perwakafan itu berlaku untuk suatu masa tertentu, dan karenanya tidak boleh disyaratkan sebagai wakaf kekal (selamanya). ${ }^{44}$

Wakaf menurut interpretasi Malikiyah, tidak terputus hak siWäqif terhadap benda yang di wakafkan. Yang terputus itu hanyalah dalam hal bertașarruf. Malikiyah beralasan dengan Hadis Ibnu Umar. Ketika Rasulullah menyatakan, "jika kamu mau, tahanlah asalnya dan sedekahkanlah hasilnya". Dari kalimat ini menurut Maliki adalah isyarat dari Rasul kepada umat untuk mensedekahkan hasilnya saja, Dengan kata lain, pemilik harta menahan benda itu dari penggunaan secara pemilikan, tetapi membolehkan pemanfaatan hasilnya untuk tujuan kebaikan, yaitu pemberian manfaat benda secara wajar sedang benda itu tetap menjadi milik siWäkif.

Dengan demikian tampak jelas bahwa wakaf atas hak satuan rumah susun terdapat pijakan hukum dari Mażhab Maliki. Dan wakaf hak atas satuan rumah susun dapat diwakafkan karena mayoritas Mażhab Fikih juga melegalkan wakaf harta bersama. Yang dalam hal ini wakaf hak atas satuan rumah susun terkandung unsur bersama.

\section{Wakaf Hak Milik Atas Satuan Rumah Susun}

Berdasarkan syarat-syarat $W$ äqif yang dikemukakan di awal-awal pembahasan dijelaskan bahwa orang yang mewakafkan harus orang yang sepenuhnya berhak untuk menguasai benda yang akan diwakafkan. siW äqif tersebut harus mukallaf (äqil bäligh) dan atas kehendak sendiri, tidak dipaksa orang lain. ${ }^{45}$

Azhar Basyir dalam bukunya Asas-asas Hukum Muamalat (Hukum Perdata Islam) juga menjelaskan bahwa orang yang mewakafkan (Wäkkif) disyaratkan memiliki kecakapan hukum atau kamāl al-Abliyyah diantaranya adalah $W$ ãqif harus merdeka dan pemilik penuh dari harta

44 Direktorat Pemberdayaan Wakaf, Fiqih Wakaf., (Departemen Agama RI. Jakarta:2006), 2-3.

${ }^{45}$ Suparman Usman, Hukum Perwakafan DiIndonesia, (Jakarta: Darul Ulum Press, 1994), 32. 
yang diwakafkan, tidak sah wakaf seorang budak karenanya tidak mempunyai hak milik. ${ }^{46}$

Perumahan merupakan salah satu kebutuhan dasar manusia baik itu sebagai tempat tinggal, usaha perkantoran, usaha berjualan dan lain sebagainya. Kita semua mengetahui bahwa untuk mencari rumah yang layak diperkotaan sangatlah sulit hal ini disebabkan karena keterbatasan tanah.

Usman Suparman dalam bukunya Hukum Perwakafan DiIndonesia juga menyatakan bahwa perbuatan mewakafkan memang perbuatan yang suci, mulia dan terpuji sesuai dengan ajaran islam. Berhubung dengan itu, maka tanah-tanah (harta wakaf) yang hendak diwakafkan itu betul-betul merupakan milik bersih dan tidak ada cacatnya ditinjau dari sudut pemilikan. $^{47}$

Akhir-akhir ini banyak permasalahan rumah susun yang mencuat dipermukaan, hal tersebut dikarenakan tingginya infestasi rumah susun yang tidak dibarengi dengan pengetahuan hukum yang terkait dengan rumah susun di kalangan masyarakat luas, sebenarnya pengaturan mengenai rumah susun mempunyai perbedaan yang cukup mendasar dengan pembangunan rumah hunian dengan tanah diatas hak milik perorangan (privat).

Pembangunan rumah susun di Indonesia adalah berdasarkan pada asas-asas kesejahteraan umum, keadilan, pemerataan serta keserasian dan keseimbangan dalam perikehidupan. ${ }^{48}$

Berdasarkan asas ksejahteraan tersebut di atas, kebijaksanaan umum pembangunan perumahan tersebut diarahkan untuk: ${ }^{49}$

a. Memenuhi kebutuhan perumahan yang layak dalam lingkungan yang sehat, secara adil dan merata, serta mampu mencerminkan kehidupan masyarakat yang berkepribadian Indonesia.

b. Mewujudkan pemukiman yang serasi dan seimbang, sesuai dengan pola tata ruang kota dan tata daerah serta tata guna tanah yang berdaya guna dan berhasil guna.

Oleh karenanya, maka pemerintah mengambil langkah dan tindakan membangun perumahan secara vertikal yang dikenal dengan Rumah Susun.

\footnotetext{
46 Azhar Basyir, Asas-asas Hukum Muamalat (Hukum Perdata Islam), cet ke-2 (Yogyakarta:UII Pres, 2004), 31

47 Suparman Usman, Hukum..., 74.

48 Sutedi Adrian, Hukum Rumah..., 157.

49 Ibid, 158.
} 
Menurut Oloan Sitorus dan Balans Sebayang ada 3 (tiga) bentuk sistem pemilikan, yaitu :

a. Sistem pemilikan perseorangan

b. Sistem pemilikan bersama yang terikat

c. Sistem pemilikan perseorangan yang sekaligus dilengkapi dengan system pemilikan bersama yang bebas (condominium). ${ }^{50}$

Dari ketiga kategori sistem pemilikan diatas, maka rumah susun jelas merupakan kategori sistem pemilikan ketiga, karena didalam rumah susun terkandung sistem pemilikan perseorangan dengan hak bersama yang bebas.

Dalam Pasal 7 ayat (1) Undang-Undang Rumah Susun, disebutkan rumah susun hanya dapat dibangun di atas tanah hak milik, hak guna bangunan, hak pakai atas tanah Negara atau hak pengelolaan sesuai dengan peraturan peundang-undangan yang berlaku.

Melihat kasus yang terjadi pada permasalahan diatas jika dihubungkan pada al-Mașlahah wakaf hak milik atas satuan umah susun merupakan tindakan ibadah yang mempunyai kemaslahatan dalam hal ini rumah susun yang diwakafkan adalah hak pakai. Sebagaimana dijelaskan dalam Pasal 7 ayat (1) Undang-Undang Rumah Susun Ditinjau dari sisi maslahat yaitu bertujuan memudahkan bagi penduduk yang ekonominya menengah kebawah atau berpenghasilan rendah yang hanya rumah susunlah satu-satunya yang dimiliki dan dengan cara mewakafkan rumah susun sebatas hanya hak pakai bukan hak memiliki.

Sedangkan menjaga dan melestarikan lingkungan hidup umat manusia dengan cara membangun sebuah perumahan didaerah perkotaan dengan tujuan mengurangi dan membantu meminimalisir penduduk yang tidak mempunyai tempat tinggal atau terlantarnya penduduk didaerah perkotaan dikarenakan terbatasnya lahan tanah untuk dibuat sebagai tempat tinggal adalah termasuk maslahah.

pembagian maslahah dari segi kualitas dan kepentingan kemaslahatan itu, diantaranya adalah kemaslahatan yang berhubungan dengan kebutuhan pokok umat manusia didunia dan diahirat (al-Maslahah al-Darüriyah), semisal memelihara memelihara agama, memelihara jiwa, memelihara keturunan, memelihara akal, memelihara harta. dan kemaslahatan yang dibutuhkan dalam menyempurnakan kemaslahatan pokok (mendasar) sebelumnya yang berbentuk keringanan untuk mempertahankan dan memelihara kebutuhan mendasar manusia (alMașlahah al-Hajjiyah).

50 Sitorus Oloan, dkk Kondominium dan Permasalahannya Mitra Kebijakan Tanah Indonesia, Cet Ke-1, (Yogyakarta, 1998) 18. 
Saifudin Zuhri dalam bukunya Ushul Fiqih (Akal Sebagai Sumber Hukum Islam) dijelaskan bahwa jika terdapat suatu kasus, dan dinyatakan jelas terdapat maslabah yang sejalan dengan maslabab yang diakui oleh syara', kemudian maslabah ini dibiarkan saja, niscaya mengakibatkan manusia akan mendapatkan kesulitan dan kesempitan. ${ }^{51}$

\section{Penutup}

Dalam permasalahan kali ini rumah susun terdapat maslahah yang sejalan dengan maslahah yang bersesuaian dengan tujuan syariat Islam, disamping memudahkan bagi penduduk yang ekonominya menengah kebawah juga bertujuan untuk keselamatan jiwa umat manusia.

\section{Daftar Pustaka}

'Alauddin, Badā'i' al-Șanā'i', Juz VI (Beirut Lebanon : Dār al-Ma'rifat, 2000).

A.W. Munawwir, Kamus al-Munawwir Arab-Indonesia Terlengkap, (Surabaya: Pustaka Progressif, 1997).

Abu Zahrah, Muhāụarāt Fi al-Waqf, (Kairo: Dār al-Fikr al-Araby, 2005).

al-Sayyid Sābiq, Fiqh al-Sunnah, Juz III, (Kairo: Dār al-Fatḥ, 1995).

Anton M. Moelyono, Kamus Besar Bahasa Indonesia, Cet. ke-2, (Jakarta: Balai Pustaka, 1989).

Azhar Basyir, Asas-asas Hukum Muamalat (Hukum Perdata Islam), cet ke-2 (Yogyakarta:UII Pres, 2004).

Departeman Pendidikan Nasional. Kamus Besar Bahasa Indonesia. (Jakarta: PT Gramedia Pustaka Utama, 2008).

Departemen Agama, UU No 41 Tahun 2004 Tentang Wakaf \& PP No 42 Tahun 2006 Tentang Pelaksanaannya, (Surabaya : Kantor Wilayah Provinsi Jawa Timur, 2007).

Departemen Agama, Wakaf Tunai Dalam Perspektif Hukum Islam, (Jakarta: Dirjen Bimas Islam Dan Penyelenggaraan Haji, 2005).

Direktorat Pemberdayaan Wakaf, Fiqih Wakaf., (Departemen Agama RI. Jakarta:2006).

Ibn Abidin, Ḥāsyiah Radd al-Mukhtār, Juz IV (Beirut Lebanon : Dār alFikr, 2005).

\footnotetext{
${ }^{51}$ Saifudin Zuhri, Ushul Fiqih (Akal Sebagai Sumber Hukum Islam), (Yogyakarta: Pustaka Pelajar, 2011), 95
} 
Kamaluddin Muhammad bin Abdul wahid, Syarkh Fath al-Qadīr, Juz VI (Beirut Lebanon: Dār al-Kutub al-Ilmiah, 1995).

Kompilasi Hukum Islam di Indonesia. (Jakarta: Akademika Pressindo, 1995).

Muhammad 'Ulaysh, Mankh al-Jalīl Syarkh ala Mukhtașar Sayyid Khalīl, (Beirut Lebanon: Dār al-Fikr,1989).

Undang-Undang Nomor 41 Tahun 2004 Tentang Wakaf

Undang-Undang Nomor 16 tahun 1985 tentang Rumah Susun

Saifudin Zuhri, Ushul Fiqih (Akal Sebagai Sumber Hukum Islam), (Yogyakarta: Pustaka Pelajar, 2011).

Saroso,dkk, Tinjauan Yuridis Tentang Perwakafan Tanah Hak Milik,,Cet, Ke-1 (Yogyakarta: Liberty, 1984).

Sitorus Oloan, dkk Kondominium dan Permasalahannya Mitra Kebijakan Tanah Indonesia, Cet Ke-1, (Yogyakarta, 1998).

Suparman Usman, Hukum Perwakafan Di Indonesia, Cet. Ke-1, Jakarta: Darul Ulum Press, 1994).

al-Zuhaily, Wahbah. al-Fiqh al-Islāmi wa Adillatubu Juz X (Beirut: Dār alFikr,1997). 